\title{
PENERAPAN PRINSIP GOOD GOVERNANCE DALAM PENYELENGGARAAN PEMERINTAHAN DI DAERAH KABUPATEN TORAJA UTARA
}

\author{
Yeheschiel B. Marewa ${ }^{1}$, Marcel Tanan ${ }^{2}$
}

\begin{abstract}
Abstrak
Penyelenggaraan pemerintahan yang baik adalah landasan bagi penyusunan dan penerapan kebijakan negara yang demokratis dalam era globalisasi yang dapat dijadikan sebagai pedoman untuk menghindari praktik tercela seperti korupsi, kolusi, dan nepotisme. Masalah utama adalah bagaimanakah mekanisme pemerintah dalam menerapkan prinsip pemerintahan yang baik.penelitian ini berlokasi di Daerah Kabupaten Toraja Utara menggunakan metode analisa kualitatif normatif. Analisa kualitatif normatif ini dilakukan secara deskriptif dan preskriptif, karena dalam penelitian ini bermaksud untuk melukiskan data dan realita terkait dengan masalah pelaksanaan prinsipprinsip kebijakan daerah dalam rangka penyelenggaraan pemerintah yang baik bersih dari korupsi, kolusi serta nepotisme. Tata kelola pemerintahan yang baik tertuju pada penyelenggaraan Penerapan Prinsip Pemerintahan di daerah kabupaten Toraja Utara, prinsip-prinsip yang di implementasikan dimaksudkan agar ada upaya untuk meningkatkan sinergi bersama dengan semua badan yang ada dikabupaten Toraja Utara, serta melibatkan peran serta masyarakat dalam mengawasi jalannya penyelenggaraan tugas dan tanggungjawab pemerintah sehingga diharapkan penyelenggaraan seluruh kegiatan pemerintah daerah kabupaten Toraja Utara bebas dari praktik Korupsi, Kolusi, dan Nepotisme.
\end{abstract}

Kata Kunci: Pemerintahan, Good Governance

\section{PENDAHULUAN}

\subsection{LATAR BELAKANG}

Penyelenggaraan pemerintahan yang baik adalah landasan bagi penyusunan dan penerapan kebijakan negara yang demokratis dalam era globalisasi. Fenomena demokrasi ditandai dengan menguatnya kontrol masyarakat terhadap penyelenggaraan pemerintahan, sementara fenomena globalisasi ditandai dengan saling ketergantungan antara bangsa, terutama dalam pengelolaan sumbersumber daya ekonomi dan aktivitas dunia usaha.

Kedua fenomena tersebut, baik demokratisasi maupun globalisasi, menuntut redefinisi peran pelaku-pelaku penyelenggaraan pemerintahan. Pemerintah sebelumnya memegang kuat kendali pemerintahan, cepat atau lambat mengalami pergeseran peran dari posisi yang serba mengatur dan mendikte ke posisi sebagai fasilitator. Dunia usaha dan pemilik modal, yang sebelumnya berupaya mengurangi otoritas negara yang dinilai cenderung menghambat aktivitas bisnis, harus mulai menyadari pentingnya regulasi yang melindungi kepentingan publik. Sebaliknya, masyarakat yang sebelumnya ditempatkan sebagai penerima manfaat (beneficiaries), mulai menyadari kedudukannya sebagai pemilik kepentingan yang juga berfungsi sebagai pelaku.

Terjadinya krisis ekonomi di Indonesia antara lain disebabkan oleh penyelenggaraan pemerintahan yang tidak dikelola dan diatur dengan baik. Akibatnya timbul berbagai masalah seperti korupsi, kolusi dan nepotisme (KKN) yang sulit diberantas, masalah penegakan hukum yang sulit berjalan, monopoli dalam kegiatan ekonomi, serta kualitas pelayanan kepada masyarakat yang memburuk.

Pemerintahan yang bersih umumnya berlangsung di negara yang masyarakatnya menghormati hukum. Pemerintahan yang seperti ini juga disebut sebagai pemerintahan yang baik. Pemerintahan yang baik itu hanya bisa dibangun melalui pemerintahan yang bersih dengan aparatur birokrasinya yang terbebas dari KKN.

Untuk mewujudkan pemerintahan yang bersih, pemerintah harus memiliki moral dan proaktif serat check and balances. Tidak mungkin mengharapkan pemerintah sebagai suatu komponen dari proses politik memenuhi prinsip pemerintahan yang bersih apabila tidak memiliki moral, proaktif serta check and balances.

\footnotetext{
${ }^{1}$ Dosen Fakultas Hukum Universitas Kristen Indonesia Paulus Makassar

${ }^{2}$ Mahasiswa Fakultas Hukum Universitas Kristen Indonesia Paulus Makassar
} 
Sehubungan dengan itu, sebuah konsep baru yang semula diperkenalkan lembaga-lembaga donor internasional, yaitu konsep tata kepemerintahan yang baik (good governance), sekarang menjadi salah satu kata kunci dalam wacana untuk membenahi sistem penye-lenggaraan pemerintahan di Indonesia. Konsep ini pertama diusulkan oleh Bank Dunia (World Bank), United Nations Development Program (UNDP), Asian Development Bank (ADB), dan kemudian banyak pakar di negara-negara berkembang bekerja keras untuk mewujudkan gagasan-gagasan baik menyangkut tata-pemerintahan tersebut berdasarkan kondisi lokal dengan mengutamakan unsur-unsur kearifan lokal..

Tata kepemerintahan yang baik dalam dokumen UNDP adalah penggunaan wewenang ekonomi, politik dan administrasi guna mengelola urusan-urusan Negara pada semua tingkat. Tata pemerintahan mencakup seluruh mekanisme, proses, dan lembaga - lembaga di mana warga dan kelompok-kelompok masyarakat mengutarakan kepentingannya, menggunakan hak hukum, memenuhi kewajiban dan menjembatani perbedaan-perbedaan di antara warga dan kelompok masyarakat.

Konseptualisasi good governance lebih menekankan pada terwujudnya demokrasi, karena itu penyelenggara-an negara yang demokratis menjadi syarat mutlak bagi terwujudnya good governance, yang berdasarkan pada adanya tanggungjawab, transparansi, dan partisipasi masyarakat. Idealnya, ketiga hal itu akan ada pada diri setiap aktor institusional dimaksud dengan memper-hatikan nilai-nilai kemanusiaan dan nilai moral yang menjiwai setiap langkah governance.

Good governance menunjuk pada pengertian bahwa kekuasaan tidak lagi semata-mata dimiliki atau menjadi urusan pemerintah, tetapi menekankan pada pelaksanaan fungsi pemerintahan secara bersama-sama oleh pemerintah, masyarakat madani, dan pihak swasta. Prinsip-prinsip yang melandasi konsep tata pemerintahan yang baik sangat bervariasi dari satu institusi ke institusi lain, dari satu pakar ke pakar lainnya. Namun paling tidak ada sejumlah prinsip yang dianggap sebagai landasan good governance, yaitu akuntabilitas, trans-paransi, dan partisipasi masyarakat. Selain itu, Good Governance yang efektif menuntut adanya koordinasi dan integritas, profesionalisme serta etos kerja dan moral yang tinggi dari ketiga pilar yaitu pemerintah, masyarakat madani, dan pihak swasta.

Berdasarkan teori dan praktik pemerintahan modern diajarkan bahwa untuk menciptakan the good governance, terlebih dahulu perlu dilakukan desentralisasi pemerintahan. Demokratisasi dan otonomisasi berpengaruh linear terhadap terwujudnya penyelenggaraan pemerintahan yang baik dan meningkatnya kualitas kesejahteraan rakyat. Wacana tentang governance yang baru muncul sekitar beberapa tahun belakangan ini, terutama setelah berbagai lembaga pembiayaan internasional mempersyaratkan good governance dalam berbagai program bantuannya. Oleh para teoritisi dan praktisi Administrasi Negara Indonesia, term good governance diterjemahkan menjadi penyelenggaraan pemerintahan yang amanah, tata kepemerintahan yang baik, pengelolaan pemerintahan yang baik dan bertanggungjawab, ada juga yang mengartikan secara sempit sebagai pemerintahan yang bersih.

Dalam rangka peningkatan kesejahteraan rakyat di Kabupaten Toraja Utara, prinsip Good Governance sudah menjadi kewajiban yang harus dijalankan dalam roda Pemerintahan Kabupaten Toraja Utara sebagaimana yang menjadi arahan secara nasional. Dalam Undang-Undang Nomor 23 Tahun 2014 menjadi cerminan pelaksanaan pemerintahan daerah berdasarkan prinsip Good Governance. Dengan demikian, pemerintah daerah dapat memberikan pelayanan maksimal kepada masyarakat sekaligu dapat memberikan kontribusi bagi perkembangan daerah, khsusunya Kabupaten Toraja Utara.

\subsection{Rumusan Masalah}

Bagaimanakah mekanisne yang dilakukan oleh Pemerintah Kabupaten Toraja Utara dalam menerapkan prinsip Good Governance ?

\subsection{Tujuan Penelitian}

Tujuan yang ingin dicapai dalam penelitian ini adalah untuk mengetahui upaya-upaya yang dilakukan pemerintah daerah Kabupaten Toraja Utara dalam menerapkan prinsip Good Governance.

\section{LANDASAN TEORI}

\subsection{Prinsip Good Governance}

Tata Kepemerintahan yang baik merupakan isu sentral yang paling mengemuka dalam pengelolaan administra-si publik dewasa ini. Sadu Wasistiono mengemukakan bahwa tuntutan akan 
good governance timbul karena adanya penyimpangan dalam penyelenggaraan negara dari nilai demokratis sehingga mendorong kesadaran warga negara untuk menciptakan sistem atau paradigma baru untuk mengawasi jalannya pemerintahan agar tidak melenceng dari tujuan semula. Tuntutan untuk mewujudkan administrasi negara yang mampu mendukung kelancaran dan keterpaduan pelaksanaan tugas dan fungsi penyelenggaraan pemerintahan negara dan pembangunan dapat diwujudkan dengan mempraktekkan good governance.

Upaya untuk mewujudkan penyelenggaraan Pemerintahan secara benar (good-governance) dan bersih (clean-government) termasuk di dalamnya penyelenggaraan pelayanan publik memerlukan unsur-unsur mendasar antara lain adalah unsur profesionalisme dari pelaku dan penyelenggara pemerintahan dan pelayanan publik. Terabaikannya unsur profesionalisme dalam menjalankan tugas dan fungsi organisasi pemerintahan akan berdampak kepada menurunnya kualitas penyelenggaraan pemerintahan dan pelayanan publik.

Profesionalisme disini lebih ditujukan kepada kemam-puan aparatur dalam memberikan pelayanan yang baik, adil, dan inklusif dan tidak hanya sekedar kecocokan keahlian dengan tempat penugasan. Sehingga aparatur dituntut untuk memiliki kemampuan dan keahlian untuk memahami dan menterjemahkan aspirasi dan kebutuhan. Lalolo Krina menjelaskan bahwa Governance diterjemahkan menjadi tata pemerintahan yaitu penggunaan wewenang ekonomi, politik dan administrasi guna mengelola urusan-urusan negara pada semua tingkat.

Tata pemerintahan mencakup seluruh mekanisme, proses dan lembaga-lembaga dimana warga dan kelompok-kelompok masyarakat mengutarakan kepentingan mereka, menggunakan hak hukum, memenuhi kewajiban dan menjembatani perbedaan-perbedaan diantara mereka.

Pengertian governace yang dikemukakan UNDP ini didukung tiga pilar yakni politik, ekonomi dan admnistrasi. Pilar pertama yaitu tata pemerintahan di bidang politik dimaksudkan sebagai prosesproses pembuatan keputusan untuk formulasi kebijakan publik, baik dilakukan oleh birokrasi sendiri maupun oleh birokrasi-birokrasi bersama politisi. Pilar kedua, yaitu tata pemerintahan di bidang ekonomi meliputi proses-proses pembuatan keputusan untuk memfasilitasi aktivitas ekonomi di dalam negeri dan interaksi di antara penyelenggara ekonomi. Sedangkan Pilar ketiga yaitu tata pemerintahan di bidang administrasi, adalah berisi implementasi proses, kebijakan yang telah diputuskan oleh institusi politik.

Sedangkan Lembaga Admnistrasi Negara (LAN) mengartikan governance sebagai proses penyelenggaraan kekuasaan negara dalam menyediakan public good dan service. LAN menegaskan dilihat dari functional aspect, governance dapat ditinjau dari apakah pemerintah telah berfungsi efektif dan efisien dalam upaya mencapai tujuan yang telah digariskan atau sebaliknya. Good dalam good governence menurut LAN mengandung dua pengertian. Pertama, nilai-nilai yang menjunjung tinggi keinginan atau kehendak rakyat, dan nilai-nilai yang dapat meningkatkan kemampuan rakyat yang dalam pencapaian tujuan kemandirian pembangunan berkelanjutan dan berkeadilan sosial. Kedua, aspek aspek fungsional dari pemerintahan yang efektif dan efisien dalam pelaksanaan tugas-tugasnya untuk mencapai tujuantujuan tersebut.

Berdasarkan pengertian ini, LAN kemudian mengemukakan bahwa good governance berorientasi pada dua hal yaitu, Pertama orientasi ideal negara yang diarahkan pada pencapaian tujuan nasional dan Kedua aspek-aspek fungsional dari pemerintahan yang efektif dan efisien dalam pelaksanaan tugasnya untuk mencapai tujuan- tujuan tersebut. Selanjutnya berdasarkan uraian tersebut LAN menyimpulkan bahwa good governance adalah penyelenggaraan pemerintahan negara yang solid dan bertanggung jawab serta efisien, dengan menjaga kesinergisan interaksi yang konstruktif di antara domain-domain negara, sektor swasta dan masyarakat.

Konsep mengenai good governance dapat ditemukan juga dalam Peraturan Pemerintah Nomor 101 Tahun 2000 tentang Pendidikan dan Pelatihan Jabatan Pegawai Negeri Sipil, dalam penjelasan Pasal 2 (d) mengartikan kepemerintahan yang baik sebagai kepemimpinan yang mengembangkan dan menerapkan prinsip-prinsip profesionalisme, akuntabilitas, transparasi, eplayanan prima, demokrasi, efisiensi, efektivitas, supremasi hukum dan dapat diterima oleh seluruh masyarakat. Governance mengasumsikan banyak aktor yang terlibat dimana tidak ada yang sangat dominan yang menen-tukan gerak aktor lain. Pesan pertama dari terminologi governance membantah pemahaman formal tentang bekerjanya institusi-institusi negara. Governance mengakui dalam masyarakat terdapat banyak pusat pengambilan keputusan yang bekerja pada tingkat yang berbeda.

Menurut UNDP, governance atau tata pemerintahan memiliki tiga domain yaitu: 
1. Negara atau tata pemerintahan (state);

2. Sektor swasta atau dunia usaha dan (private sector;)

3. Masyarakat (society).

Ketiga domain dalam Governance tersebut berada dalam kehidupan berbangsa, bernegara dan bermasyara-kat. Sektor pemerintahan lebih banyak memainkan peranan sebagai pembuat kebijakan, pengendalian dan pengawasan. Sektor swasta lebih banyak berkecimpung dan menjadi penggerak aktifitas di bidang ekonomi. Sedangkan sektor masyarakat merupakan objek sekaligus subjek dari sektor pemerintahan maupun swasta. Karena di dalam masyarakatlah terjadi interaksi di bidang politik, ekonomi, maupun sosial budaya.

UNDP dalam artikel Bappenas merekomendasikan beberapa karakteristik governance, yaitu: legitimasi politik, kerjasama dengan institusi masyarakat sipil, kebebasan berasosiasi dan partisipasi, akuntabilitas birokratis dan keuangan (finansial), manajemen sektor publik yang efisien, kebebasan informasi dan ekspresi, sistem yudisial yang adil dan dapat dipercaya.

\subsection{Prinsip Good Governance di Indonesia}

Dalam Undang-Undang Nomor 28 tahun 1999 tentang Penyelenggaraan Negara Yang Bersih dan Bebas Dari Korupsi, Kolusi, dan Nepotisme dapat dijumpai beberapa prinsip Good Governance.

1. Akuntabilitas

Menurut penjelasan Pasal 3 angka 7 Undang-Undang Nomor 28 Tahun 1999 akuntabilitas diartikan sebagai asas yang menentukan bahwa setiap kegiatan dan hasil akhir dari kegiatan penyelenggaraan negara dapat dipertanggung jawabkan kepada masyarakat atau rakyat sebagai pemegang kedaulatan tertinggi sesuai dengan ketentuan perundang-undangan yang berlaku.

2. Transparansi

Menurut penjelasan Pasal 3 angka 4 UU No. 28 tahun 1999 prinsip transparan diartikan sebagai asas yang membuka diri terhadap hak masyarakat untuk memperoleh informasi yang benar, jujur, dan tidak diskriminatif tentang penyelenggaraan negara dengan tetap memperhatikan perlindungan atas hak asasi pribadi, golongan dan rahasia negara.

3. Partisipasi

Pengertian ini tidak ditemui dalam Undang-Undang Nomor 28 Tahun 1999, tetapi misi dalam Undang-Undang Nomor 28 Tahun 1999 terlihat bahwa partisipasi masyarakat adalah hal yang hendak diwujudkan dalam penyelenggaraan pemerintahan. Dengan ringkas Sukardi menterjemahkan partisipasi sebagai upaya pembangunan rasa keterlibatan masyarakat dalam berbagai proses yang dilakukan oleh pemerintah. Pendapat ini adalah upaya melibatkan masyarakat dalam setiap proses pengambilan keputusan. Dalam teori pengambilan keputusan semakin banyak partisipasi dalam proses kelahiran sebuah policy maka dukungan akan semakin luas terhadap kebijaksanaan tersebut. Bahkan David Osborne dan Ted Gaebler menyatakan bahwa pemerintah sebaiknya berperan sebagai katalis. Hal ini dapat dipahami karena kecenderungan ke depan pemerintah yang mempunyai peranan terbatas dapat mempercepat pembangunan masyarakat.

4. Kepastian Hukum

Pengertian kepastian hukum dapat ditemui dalam Pasal 3 angka 1 Undang-Undang Nomor 28 Tahun 1999 yang menyatakan asas dalam negara hukum yang mengutamakan landasan peraturan perundang-undangan, kepatutan, dan keadilan dalam setiap pelaksanaan penyelenggaraan negara.

Sehubungan dengan good governance dalam pelaksanaan otonomi daerah, ada beberapa hal penting yang harus dilakukan di tingkat daerah. Pertama, transparasi kebijakan. Pendapat ini muncul karena pada era Orde Baru nafas birokrasi sebagai alat kekuasaan yang represif sangat menonjol. Perumusan kebijakan pembangunan dan pemerintahan yang cenderung elitis, tertutup, dan berbau nepotisme. Oleh karena itu, dalam era otonomi daerah, kondisi ini diharapkan tidak muncul lagi karena perilaku penyelenggara negara harus mengedepankan terjadinya transparasi kebijakan publik. Kedua, partisipasi masyarakat.

Walaupun dalam Undang-Undang Pemerintahan Daerah terdapat hak DPRD untuk melakukan kontrol kepada eksekutif tapi hal itu dirasakan belum cukup karena adanya indikasi bahwa DPRD dan pihak eksekutif "bermain mata" dalam menyikapi kebijakan-kebijakan politik yang strategis di daerah. Untuk mencegah ini diperlukan peranan yang optimal dari masyarakat dalam melakukan kontrol terhadap pelaksanaan pemerintahan. 
John Fenwick mengatakan bahwa dalam penataan pemerintahan daerah sudah waktunya diperlakukan prinsip the public as consumers. Hal ini dilakukan agar pemerintah lebih mengambil posisi sebagai fasilitator dan advokator kepentingan masyarakat. Dalam pelaksanaan otonomi daerah prinsip ini sudah pada tempatnya dilaksanakan di daerah karena dari dulu masyarakat hanya dilibatkan secara terbatas dalam memanajemen pemerintahan dan pembangunan. Bahkan dalam waktu yang lama rakyat lebih banyak dijadikan sebagai objek pembangunan. Peranan masyarakat hanya sebatas retorika, kepentingan birokrasi lebih menonjol dan birokrasi berubah menjadi personifikasi sekelompok elit birokrat.

Subari Sukardi berpendapat ada tiga alasan mengedepankan partisipasi masyarakat dalam pelaksanaan otonomi daerah untuk mewujudkan good governance. Pertama, kualitas program akan meningkat karena dengan partisipasi masyarakat yang besar akan memberikan jaminan bahwa tidak ada kepentingan masyarakat yang tidak dipertimbangkan dalam proses penentuan kebijakan pemerintah. Kedua, akan diperoleh legitimasi yang lebih besar karena dengan partisipasi masyarakat yang lebih besar maka rakyat akan mempunyai tanggung jawab terhadap kebijakan tersebut. Dan dukungan masyarakat akan menjadi lebih besar dalam pelaksanaan kebijakan pemerintahan. Ketiga, partisipasi masyarakat merupakan cara yang efektif untuk meningkatkan perkembangan intelektual dan moral masyarakat.

Membiasakan diri untuk memberikan akses informasi penyelenggaraan negara terhadap masyarakat. Kebiasaan instansi pemerintah tertutup terhadap pihak luar (terutama yang ingin menadapatkan informasi) harus segera dihilangkan. Ketertutupan ini dapat menimbulkan rasa curiga yang berlebihan masyarakat terhadap penyelenggaraan pemerintahan. Sikap arogan sudah tidak masanya lagi karena ini dapat menimbulkan sikap vis a vis antara masyarakat dengan jajaran penyelenggara negara di daerah.

\section{METODE PENELITIAN}

Penelitian hukum yang dilakukan bersifat normatif yang menitikberatkan pada sumber data sekunder. Data sekunder pada penelitian dapat dibedakan menjadi bahan-bahan hukum primer, bahan hukum sekunder dan bahan hukum tertier. Dalam penelitian ini, bersumber dari data sekunder sebagai berikut: a. Bahan hukum primer, yaitu bahan-bahan hukum yang mengikat, seperti Undang-Undang Dasar

Negara Republik Indonesia tahun 1945, Undang-undang Nomor 28 Tahun 1999 tentang Penyelenggaraan Negara yang Bersih dan Bebas dari KKN, Undang-Undang Nomor 20 Tahun 2001 tentang perubahan atas Undang-undang Nomor 31 Tahun 1999 tentang Pemberantasan Tindak Pidana Korupsi, Undang-Undang Nomor 23 Tahun 2014 tentang Pemerintahan Daerah, Instruksi Presiden Nomor 3 Tahun 2003 Tentang Kebijakan dan Strategi Nasional Pengembangan EGovernment, dan Instruksi Presiden Nomor 5 Tahun 2004 Tentang Percepatan Pemberantasan Korupsi.

b. Bahan hukum sekunder, yaitu bahan yang memberikan penjelasan tentang bahan hukum primer, antara lain berupa: tulisan- tulisan atau pendapat para pakar hukum, khususnya pakar hukum pidana mengenai pelaksanaan prinsip-prinsip kebijakan daerah dalam rangka penyelenggaraan pemerintah yang baik bersih korupsi, kolusi serta nepotisme.

c. Bahan hukum tertier, yakni bahan yang memberikan petunjuk maupun penjelasan terhadap bahan hukum primer dan sekunder, seperti Kamus Besar Bahasa Indonesia, kamus bahasa Inggris, dan kamus hukum.

Jenis data yang dijadikan bahan penelitian dalam penelitian ini meliputi bahan dalam penelitian hukum normatif yang lebih menitik beratkan pada penelitian data sekunder. Data sekunder yaitu data yang diperoleh melalui studi kepustakaan baik data sekunder yang bersifat publik maupun data yang dipublikasikan, yang merupakan data sekunder di bidang ilmu hukum. Sumber data yang dipergunakan terdiri dari data primer dan data sekunder. Untuk data sekunder, sumber data yang dipergunakan lebih menitikberatkan pada berbagai dokumen peraturan perundang-undangan, sumber-sumber hukum dan peraturan perundang-undangan negara lain, hasil penelitian dan kegiatan lainnya baik nasional maupun internasional.

Metode analisa data yang dipakai dalam penelitian ini adalah metode analisa kualitatif normatif yaitu analisis data non statistik yang disesuaikan dengan data yang akan dikumpulkan yaitu data yang diskriptif. Analisa kualitatif normatif ini dilakukan secara deskriptif dan preskriptif, karena dalam penelitian ini bermaksud untuk melukiskan data sebagaimana adanya dan juga bermaksud melukiskan 
realita terkait dengan masalah pelaksanaan prinsip-prinsip kebijakan daerah dalam rangka penyelenggaraan pemerintah yang baik bersih korupsi, kolusi serta nepotisme.

\section{HASIL DAN PEMBAHASAN}

Implementasi prinsip pemerintahan yang baik di daerah kabupaten Toraja Utara tidak lepas dari tingginya tingkat kesadaran hukum apratur setempat dan pemahaman akan peraturan perundangundangan yang diterapkan pada lingkungan kerjanya. Pada kantor bupati daerah Toraja Utara melalui staf dan aparaturnya menyatakan bahwa berbagai peraturan kebijakan sudah diterapkan dalam segala aspek, terlebih berkaitan dengan hal-hal mengenai pelaksanaan suatu keputusan pejabat yang berwenang terkait dengan masalah sosial kemasyaraka-tan senantiasa berpegang teguh pada prinsip pemerin-tahan yang baik, hal ini dibuktikan dengan data sejak tahun 2015-2017 kasus korupsi tidak mencolok pada wilayah ini demikian juga halnya dalam suatu peraturan daerah yang berlaku tidak terdapat satupun Pasal yang bersifat diskriminatif terhadap warganya. Namun demikian pihak pemerintah setempat senantiasa melakukan perluasan penerapan prinsip tersebut tidak hanya terbatas pada lingkungan aparat pejabat setempat tetapi juga mencakup seluruh elemen masyarakat khususnya daera Toraja Utara, adapun upaya yang dilakukan antara lain yakni :

a. Pemberitaan Media

Media mempunyai peranan penting dalam pembentu-kan opini dan penyebarluasannya. Setiap kebijakan dan hal-hal yang berhubungan dengan pemerintah selalu menjadi topik utama di berbagai media massa. Citra media massa yang kredibel dan independen saat ini seperti sebuah kemustahilan. Media sering mengutama-kan keuntungan praksis meskipun berita yang ia bawakan tidak sesuai kenyataan atau tanpa klarifikasi dari pihak yang bersangkutan. Meskipun tidak semua media massa demikian, namun ibaratnya sebuah kebohongan yang diberitakan berkali-kali bisa menjadi-kannya "kebenaran" maka medialah yang memiliki peranan tersebut.

b. Kurangnya Pengetahuan Masyarakat

Masyarakat Indonesia memang telah mulai banyak mengenal pengetahuan dan berkurangnya jumlah buta aksara. Akan tetapi hal ini tidak dibarengi dengan edukasi tentang bagaimana pemerintah bertindak, mengambil keputusan, dan prestasi-prestasinya. Hal ini menjadi faktor selanjutnya yang menjadi PR bagi pemerintah untuk mengedukasi masyarakat dengan bantuan berbagai pihak termasuk media massa.

Dua faktor di atas merupakan sedikit dari beberapa hal yang mempengaruhi anggapan atau opini masyarakat bahwa pemerintahan yang bersih hanya dalam impian semata. Kemudian pembahasan kita berlanjut ke arah internal pemerintah itu sendiri, bagaimana seharusnya dan apa upaya-upaya yang perlu dilakukan demi terciptanya pemerintah yang bersih. Di bawah ini adalah beberapa hal yang perlu ada dan dilaksanakan oleh semua pihak, yaitu :

a. Menanamkan Budi Pekerti

Sebuah langkah yang hendaknya diambil oleh pemerintah adalah upaya menanamkan dan menumbuhkan budi pekerti dan sikap nasionalisme kepada penerus bangsa. Ini merupakan upaya jangka panjang bagi terwujudnya "revolusi mental" yang didengung-dengungkan pemerintah saat ini. Dengan tumbuhnya generasi yang memiliki moral baik dan sifat nasionalisme akan membuat pemerintah di masa mendatang benar-benar profesional seperti yang diharapkan. Bagaimana caranya agar terwujudnya rencana ini diperlukan penggabungan (Fusi) antara Pendidikan Kewarganegaraan dan Pendidikan Agama. Pemisahan kedua aspek pendidikan tersebut menyebabkan kesulitan membangun budi pekerti dan nasionalis-me pada saat yang bersamaan.

b. Transparansi Anggaran

Ekonomi termasuk bidang yang sangat kompleks dan rawan penyimpangan. Bahkan, bisa dikatakan seluruh aktivitas penyelewengan jabatan adalah representasi dari keinginan manusia yang tidak terbatas. Karena itu, pemerintah seharusnya terbuka dan transparan dalam perancangan anggaran sehingga dapat dikoreksi oleh para ahli di bidangnya. Keterbukaan dan transparansi anggaran kepada masyarakat akan memperkecil timbulnya KKN.

c. Edukasi Kepada Publik dan Pengkaderan

Masyarakat sudah seharusnya mendapatkan penjelasan dari pemerintah tentang pekerjaan yang mereka lakukan karena pemerintah harus mendapat dukungan dari publik yang telah memilihnya. Partai politik sebagai wadah penjaring kader-kader baru dianjurkan untuk lebih ketat dalam pemilihan kader agar hanya orang-orang profesional dan kredibel yang masuk ranah politik. Hal ini 
dimaksudkan agar pemerintah diisi oleh orang yang benar-benar layak di bidangnya dan mampu menjadi pengayom masyarakat bukan pemakan uang rakyat.

d. Kepastian Hukum

Sekarang ini telah menjadi trend bahwa hukum tajam ke bawah, tumpul ke atas. Fenomena ini membuat masyarakt merasa terciderai karena seharusnya negara indonesia adalah negara hukum (UUD 1945 Pasal 1 ayat 3). Tetapi hukum di Indonesia tidak obyektif, sehingga orang- orang yang memiliki uang mampu membeli hukum itu. Dilema yang makin diperkeruh dengan banyaknya kepentingan-kepentingan lain yag masuk keranah hukum.

e. Legislatif Sebagai Mitra Kritis Eksekutif

Lembaga legislatif (DPR dan DPD) yang salah satu fungsinya menilai kinerja pemerintah agar tidak melenceng atau merugikan rakyat harus dioptimalkan. Sudah seharusnya legislatif menjadi mitra kritis eksekutif. Begitu pula anggapan oposisi dan koalisi tidak sewajarnya dimutlakkan karena legislatif harus mengutamakan kepentingan rakyat dari kepentingan lainnya.

f. LSM Sebagai Wadah Aspirasi Masyarakat

Lembaga Swadaya Masyarakat (LSM) adalah lembaga yang tidak ada intervensi pemerintah. Lembaga-lembaga swadaya masyarakat yang telah banyak berkembang di masyarakat hendaknya digunakan oleh pemerintah untuk menilai kinerjanya. Pemerintah tidak akan mampu berjalan sendiri karena LSM lah yang lebih "mengerti" keadaan masyarakat. Pemerintahan yang bersih akan terwujud bila mau menerima realita berupa kritik dari LSM.

Apabila langkah-langkah di atas mampu terwujud, maka keinginan masyarakat untuk terciptanya pemerin-tah yang bersih akan bisa terealisasi. Selain itu, dukungan dan keaktifan masyarakat merupakan faktor penentu. Jika masyarakat tidak mendukung akan mustahil terwujud pemerintah yang bersih karena masyarakat adalah aktor utama dalam sistem pemerintahan yang demokratis

\section{KESIMPULAN DAN SARAN}

\subsection{Kesimpulan}

Penerapan Prinsip Pemerintahan yang baik di daerah kabupaten Toraja Utara, dimaksudkan agar ada upaya untuk meningkatkan sinergi bersama dengan semua badan pemerintahan yang ada dikabupaten Toraja Utara, dengan melibatkan peran serta masyarakat dalam mengawasi jalannya penyelenggaraan tugas dan tanggungjawab pemerintah daerah secara transparan, memberikan informasi yang utuh melalui edukasi dan publikasi, serta akuntabel sehingga diharapkan penyelenggaraan seluruh kegiatan pemerintah di daerah kabupaten Toraja Utara bebas dari praktik Korupsi, Kolusi, dan Nepotisme.

\subsection{Saran}

Perlunya peningkatan kapasitas dan pengetahuan terhadap prinsip-prinsip Good Governance bagi aparatur pemerintahan Kabupaten Toraja Utara. Hal ini perlu dilakukan secara berkesinambungan, agar pengetahuan mengenai prinsip Good Governance tetap melekat, khususnya dalam diri aparatur pemerintahan Kabupaten Toraja Utara. Selain itu, diperlukan sinergitas antara seluruh stakeholder dalam penyelenggaraan pemerintahan, baik eksekutif, legislatif, yudikatif dan kelompok-kelompok masyarakat. Dengan begitu pelayanan kepada masyarakat dapat berjalan selaras dengan prinsip good governance.

\section{DAFTAR PUSTAKA}

Aziz Syamsudin. 2011. Proses dan Teknik Perundang-undangan. Sinar Garfika : Jakarta Billah, 2001. Dalam Pendahuluan Kumpulan Makalah Workshop and Seminar on Good Governance : Surabaya.

Budi Harsono 2009, Legislatif Drafting, Teori dan Teknik Pembuatan Peraturan Daerah, Universitas Atma Jaya : Yogyakarta

Budiman NPD. 2005 Ilmu Pengantar Perundang-undangan. UII Press : Yogyakarta.

Ni'matul Huda. 2013. Hukum Tata Negara. Raja Grafindo Persada : Jakarta

Riyadi Soeprapto. 2004. Pengembangan Kapasitas Pemerintah Daerah Menuju Good Governance. Habibie Center : Jakarta

Rosyini Ranggawidjaja. 2010. Pembentukan Peraturan Negara di Indonesia 
Sadu Wasistiono. 2003. Kapita Selekta Penyelenggaraan Pemerintahan Daerah. Fokus Media : Bandung 